\title{
Determinants of occupational injuries among building construction workers in Kampala City, Uganda
}

\author{
Arthur Kiconco $^{1 *}$ (D), Nathan Ruhinda ${ }^{1}$, Abdullah Ali Halage ${ }^{1}$, Stephen Watya', William Bazeyo ${ }^{1}$, \\ John C. Ssempebwa ${ }^{1}$ and Joseph Byonanebye ${ }^{2}$
}

\begin{abstract}
Background: Globally, about 1000 people die and close to 860,000 people sustain injury at work daily. Injury prevention and control require contextual evidence, although most studies in Uganda have focused on general causes. Factors associated with occupational injuries among building construction workers were assessed in this study.

Methods: A cross-sectional study among building construction workers was conducted in Kampala, Uganda. A standardized semi-structured questionnaire was used to collect data. Three hundred nineteen (319) participants were randomly and proportionately selected from 57 construction sites. Descriptive statistics were used to describe the variables while generalized linear modeling was used to estimate the crude/adjusted prevalence ratios.

Results: The prevalence of occupational injuries was 32.4\%. Most injuries, approximately $70 \%$ occurred among nightshift workers. Age of $\leq 24$ years (APR: $2.09 \mathrm{Cl}: 1.20-3.65, P=0.009$ ); daily income in or above the second quartile-USD $\geq 3.2$ (APR: 1.72, Cl: 1.06-2.80, $P=0.028$ ); job dissatisfaction (APR: 1.63, Cl: 1.17-2.27, $P=0.004$ ); job stress (APR: 1.72, Cl: 1.22-2.41, $P=0.004$ ); poor safety environment (APR: 1.51, Cl: 1.10-2.05, $P=0.009$ ); PPE provision (APR: 1.47, Cl: $1.05-2.05, P=0.02$ ) and routine use of PPE (APR: $0.57, \mathrm{Cl}: 0.34-0.95, P=0.03$ ) were significantly associated with occupational injuries.

Conclusion: There was a relatively high prevalence of injuries mostly resulting from cuts and mostly suffered on night duty. Upper and lower extremities were the most hurt parts of the body during injury leading to loss of a substantial number of productive days. This could affect the health and wellbeing of construction workers. Most of the factors significantly associated with occupational injuries are modifiable thus an opportunity to address the problem. Efforts towards integrating education for behaviour change, advocacy and training workers to demand for their rights to safe and protection at work and legislation enforcement can help reduce occupational injury occurrence.
\end{abstract}

Keywords: Occupational injuries, Linear models, Perception, Safety, Construction workers, Workplace

\section{Background}

Occupational injuries are a public health and economic problem globally with about $5-7 \%$ of all fatalities in industrial countries attributable to work-related injuries [1]. In low-income countries, non-occupational health problems pose a bigger burden, but work-related injuries also pose a substantial burden [2]. The International Labour Organization (ILO) estimates that 860,000

\footnotetext{
* Correspondence: artkic@gmail.com

${ }^{1}$ Makerere University School of Public Health, P. O. Box 7072, Kampala, Uganda

Full list of author information is available at the end of the article
}

people sustain injury or ill health at work daily, and nearly 1000 people die worldwide as a result of occupational injuries daily [3]. In 2010 alone, over 313 million suffered non-fatal injuries at work globally leading to at least 4 days of absence from work [3]. Every year, 350,000 deaths are due to fatal occupational injuries; but 270 million serious non-fatal injuries also occur [4].

Construction industry is more risky $[5,6]$ as compared to other industries due the high burden of occupational hazards $[7,8]$. Building construction workers are three to four times more likely to be killed and twice as likely

(c) The Author(s). 2019 Open Access This article is distributed under the terms of the Creative Commons Attribution 4.0 International License (http://creativecommons.org/licenses/by/4.0/), which permits unrestricted use, distribution, and reproduction in any medium, provided you give appropriate credit to the original author(s) and the source, provide a link to the Creative Commons license, and indicate if changes were made. The Creative Commons Public Domain Dedication waiver (http://creativecommons.org/publicdomain/zero/1.0/) applies to the data made available in this article, unless otherwise stated. 
to be injured compared to workers in other occupations $[9,10]$. The rate of the injuries is low in high-income countries than in middle and low-income countries (LMICs) despite the low rate of reporting of occupational injuries in LMICs. It is estimated that more than 16,000 fatal occupational injuries occur in the established market economies with a fatality rate of 4.2 and accident rate of 3240 per 100,000 workers respectively. These are lower than the fatality and accident rates in developing countries like in Asia at 21.5 and 16,434 per 100,000 workers respectively and Sub-Saharan Africa at 21 and 16,012 per 100,000 workers respectively [11].

In 2013, occupational injuries in Tanzania were estimated at 36 fatal injuries per 1000 workers-a fatality rate of 23.73 per 100,000 workers [12]. Rwanda reported a total of in 482 non-fatal accidents among 130 respondents in a 780 man-months period construction industry in 2012 and building construction projects were found to have higher accident rates compared to other civil engineering projects [13].

In Uganda, work-related injuries continue to be a big problem and the situation of the building construction industry is considered one of the most dangerous [14]. Reports from Uganda's Ministry of Gender, Labour and Social Development (MoGLSD) show that injuries among construction workers accounted for $13 \%$ of all occupational injuries in Kampala in 2003 and were the third contributor of injury events [15]. Over $60 \%$ of all occupational accidents in the country occur in Kampala [16] and the injury and fatality rate for Kampala district stood at 4248 per 100,000 and 92 per 100,000 workers respectively in 2014 [17]. Uganda just as other lowincome countries is on the struggle to meet population needs. Building construction is one of the fast growing industries in Kampala city characterized by frequent accidents [14]. Occurrence of occupational injuries at construction sites is as a result of complex interactions between individuals and the work environment; however, proximate probable risk factors include poor service and maintenance of construction equipment, inadequate training of workers, and congestion on building sites [17]; inadequate supervision, poor quality materials, psychological problems and inadequate lighting for night shifts workers [14].

Several measures to prevent and control occupational injuries in Uganda include Occupational Safety and Health (OSH) Act of 2006, which calls for employers to protect their workers by ensuring that all possible measures to ensure that workers and public are free from danger at workplaces, however, occupational injuries continue to claim lives at construction sites. Contextual evidence is required for successful injury prevention and control although most studies in Uganda have focused on general causes rather than association of different factors with occupational injury. Therefore, our study explored the socio-demographic, work environment and behavioral factors associated with occupational injuries in order to inform relevant injury prevention and control efforts.

\section{Methods \\ Study design and period}

A descriptive cross-sectional study in which quantitative data was collected was conducted between April and May 2016.

\section{Study setting}

The study was carried out in Kampala City-Uganda's capital city located in Central Uganda between April and May 2016. Kampala district in general has a population of $1,516,210$ people, at a $2.02 \%$ growth rate per annum since 2002 [18]. As the population grows, infrastructural development in Kampala is also fast compared to other urban areas in Uganda.

\section{Study population}

The study involved building construction workers aged 18 years of age and above and were actively engaged in the industry during the study period.

\section{Eligibility}

Building construction workers of 18 years of age and above who had worked in the construction industry for at least 6 months prior to the study and were still actively engaged in the construction industry and available at construction sites during the study period were recruited for the study. Workers who had disabilities that could not allow them to fully express their views in regard to the study questions were not involved in the study.

\section{Sample size}

Using Kish Leslie (1964) formula for cross-sectional studies and prevalence of occupational injury at $27 \%$ [19], a sampling error $(\delta)$ of $5 \%$ at $95 \%$ confidence level, a minimum sample of 303 respondents was computed. A response rate of over $99.5 \%$ has been reported in similar studies $[20,21]$, therefore, a non-response rate of $5 \%$ was considered thus a final sample size of 319 respondents.

\section{Sampling procedure}

Simple random sampling with sampling proportionate to size was used. Lists of registered building sites were obtained from Department of Physical Planning at Kampala Capital City Authority (KCCA) before making the general list for sampling. A total of 455 building construction sites across the five divisions of Kampala City were considered. Sites in each division were assigned 
computer generated random numbers and 12\% were selected resulting in 57 sites.

To select workers, a list of all workers at each site including supervisors was obtained from the foreman after approval from the site manager and each worker was assigned a number. A number of workers proportionate to the number of workers at respective sites was randomly selected. In cases where a selected respondent declined to participate, the next number on the list was considered.

\section{Data collection tools and procedure}

Face to face interviews using a questionnaire with close ended and semi-structured questions were used to collect the data. Trained research assistants visited construction sites, making appointments with the selected respondents and then interviewed them at appropriate times and in privacy.

\section{Variable measurement}

To assess injury prevalence, we asked about history of occupational injury within 6 months prior to the study that led to at least 6 hours off the job. To assess factors including poor safety of the work environment, workplace supervision, risk taking behaviour, job satisfaction and job stress; a validated three-scale item standardized worker's response device (WRD) questionnaire [22] was adapted with adjustments to fit in Uganda's context supplemented with Jenkins four item sleep scale [23] to assess sleeping disorder. For the WRD, factors were measured by summing scores of individual items under each factor. The 90th percentiles of the scores for each factor was used as threshold value where scores $<90$ th percentile were taken as poor and those $\geq 90$ th percentile were taken as good [20, 22].

\section{Data analysis}

Data was analysed using Stata ${ }^{\circ}$ 12.0. At univariate analysis frequencies and percentages were used to describe the distribution of respondents in each of the study variables. The association of each of the independent variables was assessed at bivariate analysis using generalized linear modelling with modified Poisson regression. Crude Prevalence Ratios (cPRs) at 95\% confidence interval were calculated. Multivariate analysis of all variables with $p$-value $\leq 0.20$ to adjust for confounding to generate adjusted Prevalence Ratios (APRs) and effect modification was assessed. All statistical tests were two-sided, 95\% confidence intervals were used and $p$-values of $\leq 0.05$ were considered statistically significant.

\section{Quality control}

One day training of research assistants was conducted to ensure quality data collection. The training covered question clarity, interview skills as well as appropriate information capturing. The questionnaire was pretested on 10 participants at a site that was later excluded in the study and then adjusted in respect to the pretesting results to ensure validity of the questions.

\section{Results}

A total of 318 respondents from 58 construction sites were interviewed. The response rate of this study was $99.7 \%$, and only one respondent did not complete the questionnaire.

\section{Socio-demographic characteristics and injury prevalence among construction workers}

Table 1 shows the socio-demographic characteristics of the respondents. Majority were aged 25-35 with age range $18-57$ years, mean age 28.2 and standard deviation (SD) 7.0. Most (90.9\%) of the respondents were males. Close to a half (47.2\%) had completed secondary school and majorly $(72.6 \%)$ temporary workers. Daily income ranged from 1.9-2.7USD (first quartile), 3.2-4.0USD (second), 4.9-5.4USD (third quartile) to $\geq 6.8 \mathrm{USD}$ (fourth quartile) with majority (33.65\%) in the first quartile. Majority (72.6\%) of the workers did not have contracts with their employers and the biggest percentage $(63.5 \%)$ had spent more than a year in building construction work with majority of causal labourers having experience of 1-4 years (Fig. 1). Slightly more than a half (51.2\%) especially causal labourers (Fig. 2) worked for more than $10 \mathrm{~h}$ a day yet the daily income of $59.43 \%$ of the workers was in the second quartile and below especially the causal labourers whose daily income fell in the first quartile (Fig. 3). Injury prevalence was higher among those below 35 years, males, temporary employed, worked for over $10 \mathrm{~h}$ and those whose daily income fell in the upper 2 quarters (Table 1).

\section{Characteristics of workers who had suffered an occupational injury}

Table 2 shows characteristics of workers who had occupational injuries. The prevalence of occupational injuries was $32.4 \%$. The majority (68.9\%) of the respondents suffered injury while on night duty. Of those who experienced injuries, $27.2 \%$ were cut by sharp objects. The majority (70.9\%) sought medical care after the injury and close to a half (46.6\%) went back to work in less than 1 day.

\section{Distribution of respondents by work environment characteristics and injury prevalence}

As indicated in Table 3, majority (41.2\%) of the respondents were casual labourers (porters) and over a half $(52.2 \%)$ never had any health and safety training. Even those who had ever had health and safety training, majority $50.7 \%(77 / 152)$ were trained at their workplaces. 
Table 1 Socio-demographic Characteristics and Injury Prevalence among Construction Workers in Kampala, Uganda

\begin{tabular}{|c|c|c|}
\hline \multirow[t]{2}{*}{ Variables } & \multicolumn{2}{|l|}{ Injury } \\
\hline & Yes n (\%) & No n (\%) \\
\hline \multicolumn{3}{|l|}{ Age (years) } \\
\hline $35+$ & $11(22.0)$ & $39(79.0)$ \\
\hline$\leq 24$ & $42(36.52)$ & $73(63.48)$ \\
\hline $25-35$ & $50(32.68)$ & $103(67.32)$ \\
\hline \multicolumn{3}{|l|}{ Sex } \\
\hline Female & $6(20.69)$ & $23(79.31)$ \\
\hline Male & $97(33.56)$ & $192(66.44)$ \\
\hline \multicolumn{3}{|l|}{ Marital status } \\
\hline Single & $54(35.06)$ & $100(64.94)$ \\
\hline Married & $45(29.61)$ & $107(70.39)$ \\
\hline Separated/Widowed & $4(33.33)$ & $8(66.67)$ \\
\hline \multicolumn{3}{|l|}{ Highest Education Level } \\
\hline Tertiary & $28(34.15)$ & $54(65.85)$ \\
\hline Primary & $24(30.77)$ & $54(69.23)$ \\
\hline Secondary & $49(32.67)$ & $101(67.33)$ \\
\hline None & $2(25.00)$ & $6(75.00)$ \\
\hline \multicolumn{3}{|l|}{ Employment Terms } \\
\hline Contract & $25(28.74)$ & $62(71.26)$ \\
\hline Temporary & $78(33.77)$ & $153(66.23)$ \\
\hline \multicolumn{3}{|c|}{ Experience in building Construction } \\
\hline $1-4$ years & $28(24.14)$ & $88(75.86)$ \\
\hline$<1$ year & $44(33.59)$ & $87(66.41)$ \\
\hline$>4$ years & $31(43.66)$ & $40(56.34)$ \\
\hline \multicolumn{3}{|l|}{ Working hours } \\
\hline $8-10$ & $44(28.39)$ & $111(71.61)$ \\
\hline $11-12$ & $59(36.20)$ & $104(63.80)$ \\
\hline \multicolumn{3}{|l|}{ Daily income (Quartiles) } \\
\hline First & $24(23.3)$ & $83(38.60)$ \\
\hline Second & $18(17.48)$ & $64(29.77)$ \\
\hline Third & $32(31.07)$ & $38(17.67)$ \\
\hline Fourth & $29(28.16)$ & 30 (13.95) \\
\hline
\end{tabular}

Over $80 \%$ were on sites without written safety and health policy/program and onsite hazard communication measures. More than quarter $(31.45 \%)$ of the workers were not provided with PPE by employers and had to purchase on their own. Injuries were most prevalent among causal labourers and those without safety training.

\section{Behavioural characteristics of the workers and injury prevalence}

Among construction workers who drank alcohol, only $31.5 \%$ (29/92) drunk before going to work and only $34.8 \%$ (32/92) drunk while at work (Table 4). Only 10.1\% (33/318) chewed khat, of whom $60.6 \%$ (20) chewed khat before going to work. More than a quarter (30.2\%) experienced sleeping disorder, $24.1 \%$ (77/318) experienced job dissatisfaction, 51.8\% (165/318) had job stress, and 25.2\% (80/318) exhibited risk-taking behaviour. More than a quarter (100/ 318) of the respondent provided PPE to themselves and only $32.7 \%(104 / 318)$ always used PPE (Table 4).

\section{Factors associated with occupational injuries}

Table 5 shows the factors that are associated with occupational injuries after adjusting for all other factors. Age of $\leq 24$ years (APR: 2.09 CI: $1.20-3.65, P=0.009$ ); daily income in or above the second quartile-USD $\geq 3.2$ (APR: 1.72, CI: $1.06-2.80, P=0.028$ ); job dissatisfaction (APR: 1.63, CI: $1.17-2.27, P=0.004)$; job stress (APR: 1.72 , CI: 1.22-2.41, $P=0.004$ ); poor safety environment (APR: 1.51, CI: $1.10-2.05, P=0.009$ ); PPE provision (APR: 1.47 , CI: $1.05-2.05, P=0.02$ ) and routine use of PPE (APR: $0.57, \mathrm{CI}: 0.34-0.95, P=0.03$ ) were significantly associated with occupational injuries.

\section{Discussion}

This study describes the characteristics and determinants of occupational injuries among building construction workers in Kampala City. We explored the prevalence and the association of socio-demographic, work environment and behavioural factors with occupational injuries. There was a high prevalence of occupational injuries of $32 \%$

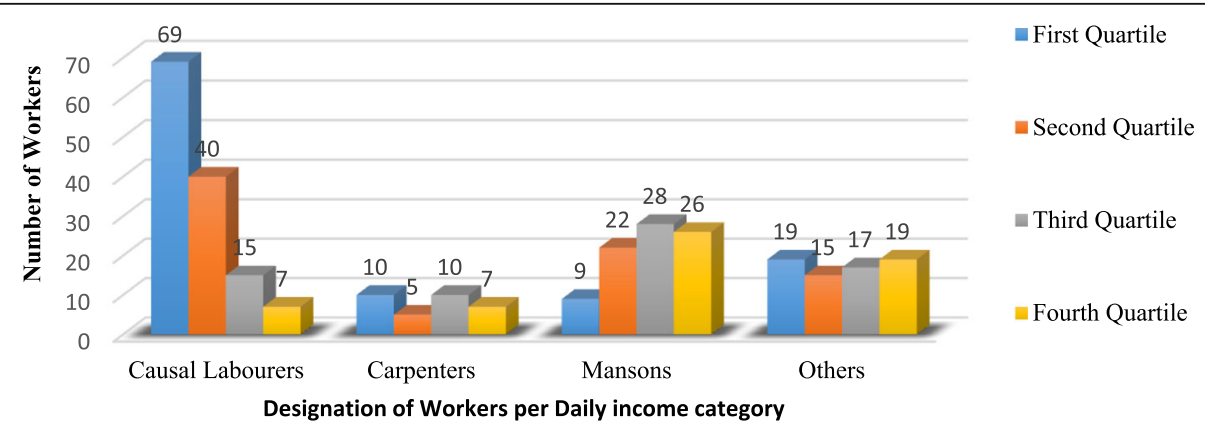

Fig. 1 Distribution of construction workers by designation and experience 


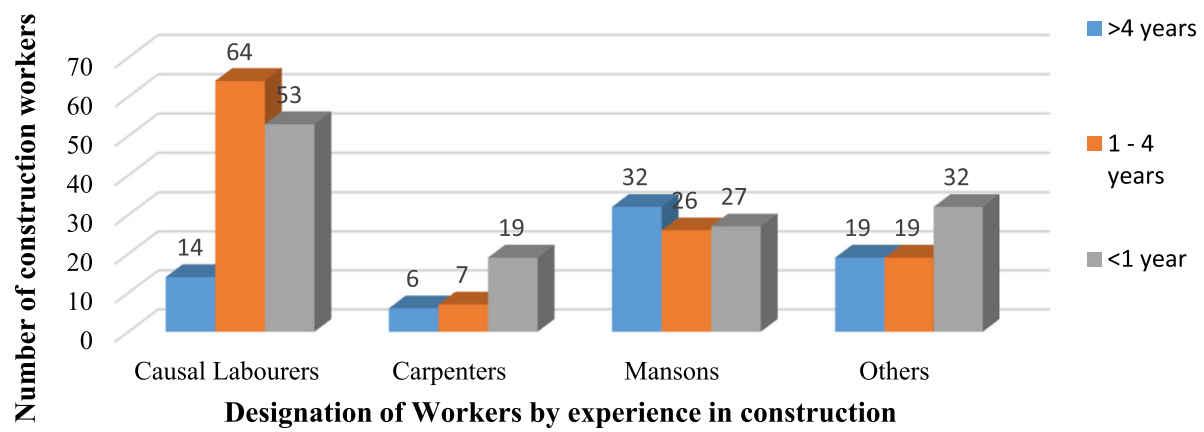

Fig. 2 Distribution of construction workers by designation and working hours

among workers. This prevalence is not surprising since many construction sites did not have onsite hazardcommunication measures, written safety and health policy, and majority did not use personal protective equipment (PPE). A higher prevalence has been reported elsewhere, 46.2\% in Mit-Ghamr [24] and 38.7\% in Gondar [21] cities of Egypt, as well as 38.3\% [25] in Ethiopia. This study also shows that the biggest percentage of workers had suffered injury while on night duty. This is in line with Dembe, et al. [26] who reported extended working hours and another study that reported inadequate lighting for night shifts [14] as predictors for occupational injuries. Non-use of PPE calls for efforts towards behaviour change among workers while neglected safety and health to promote safety at the workplaces should be observed.

In this study, over a quarter of those who experienced injuries were cut by sharp objects, while the rest were pierced by construction materials/equipment, hit by falling objects, fell from heights, electric shocks, fell at the same level, held between objects or hit by colleagues. These are among the fatal four as described by ILO [27] and the United States Occupational Safety \& Health Administration [28]. Similar results have also been reported by many scholars including falls $[10,17,24,29]$, electrocution [10] being struck by falling objects [10, 17] being hit by machinery and hand tools [17, 20,30]; and cutting edges $[17,19]$. Majority of the respondents got injuries on their hands, feet, legs or head/neck, shoulder, chest, eye, back or abdomen. This indicates that personal protective equipment targeting extremities and other safe working practices would make a change in building construction. These findings are in line with others who reported injuries to the upper and lower limbs [24], upper trunk and extremities, i.e. eyes, neck, back, shoulder, arm, finger, and hand [31]. Loss of productive time is an important issue as far as occupational injuries are concerned and this study reveals that over a half of those who suffered injuries could only get back to work after two to four or more days. Just as it is reported that nonfatal occupational injuries led to at least 4 days of absence from work in 2010 [3]. In Denmark, the mean days of work lost due to injury was 3.21 in 2013 which lead to an estimated 1,822,000 workdays which were about $6 \%$ of the total absence from work due to all types of illness [32]. This poses a big burden on both the health system and families [27] as besides men being the majority yet most of the times breadwinners in most homes, they may also require care during the time of nursing the injuries. It has been noted that in many cases, other family members may have to forfeit their jobs so as to care for an injured worker [33] and in the US, 2007 estimates indicate that the direct and indirect cost of work injuries was $\$ 192$ billion [34]. Indeed, an earlier study had indicated that the cost of home care of injured family members by other household members was about 6.2 million workdays a year an equivalent of

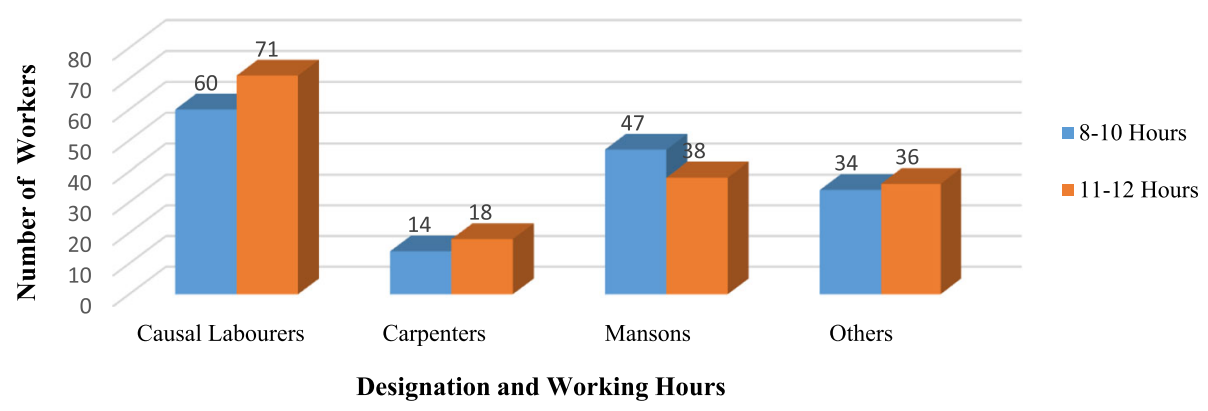

Fig. 3 Distribution of construction workers by designation and daily income 
Table 2 Prevalence and characteristics of occupational injury among construction workers in Kampala, Uganda

\begin{tabular}{|c|c|c|}
\hline Variables & Frequency $(n=318)$ & Percent (\%) \\
\hline \multicolumn{3}{|c|}{ Had an injury at work in the last 6 months } \\
\hline Yes & 103 & 32.4 \\
\hline No & 215 & 67.6 \\
\hline \multicolumn{3}{|l|}{ What led to injury } \\
\hline Fell from height & 16 & 15.5 \\
\hline Pierced by construction materials & 19 & 18.4 \\
\hline Cut by sharp object z & 28 & 27.2 \\
\hline Hit by falling object & 18 & 17.5 \\
\hline Others $^{\mathrm{a}}$ & 22 & 21.4 \\
\hline \multicolumn{3}{|l|}{ Part of the body hurt } \\
\hline Hand & 26 & 25.2 \\
\hline Foot & 21 & 20.4 \\
\hline Leg & 19 & 18.5 \\
\hline Others $^{b}$ & 37 & 35.9 \\
\hline \multicolumn{3}{|c|}{ Sought medical care following the injury } \\
\hline Yes & 73 & 70.9 \\
\hline No & 30 & 29.1 \\
\hline \multicolumn{3}{|l|}{ Admitted after injury } \\
\hline Yes & 14 & 13.6 \\
\hline No & 89 & 86.4 \\
\hline \multicolumn{3}{|c|}{ Work shift involved in at the time of injury } \\
\hline Day & 32 & 31.1 \\
\hline Night & 71 & 68.9 \\
\hline \multicolumn{3}{|l|}{ Time taken to go back to work } \\
\hline$\leq 1$ day & 48 & 46.6 \\
\hline 2-3 days & 19 & 18.4 \\
\hline$>4$ days & 36 & 35.0 \\
\hline
\end{tabular}

aElectrocution, Fell at the same level, Held between objects, Hit by colleague

${ }^{\mathrm{b}}$ Head/neck, shoulder, Chest, Eye, Back, Abdomen

$\$ 162$ million [35]. In addition to that, in an economy where majority of the workers are men, on temporary recruitment, and not covered by any kind of insurance, it means that all the costs of the injuries maybe borne by the injured workers or their families which over burdens the families.

Long experience in building construction work did not show significant association with occupational injuries and illness in this study. Many other studies [36, 37] have however reported association of long job experience and injury occurrence. Chau and colleagues [20] reported work experience less than 5 years to be associated with injuries, but Bena and others [38] in their study found that injury rates decreased with increase in job tenure with high risk among those who had worked for less than 6 months and risk reduction after 2 years of work experience. Other studies have
Table 3 Work Environment Characteristics among construction workers in Kampala, Uganda

\begin{tabular}{|c|c|c|}
\hline \multirow[t]{2}{*}{ Variables } & \multicolumn{2}{|l|}{ Injury } \\
\hline & Yes n (\%) & No $n(\%)$ \\
\hline \multicolumn{3}{|l|}{ Work designation } \\
\hline Carpenters & $12(37.50)$ & $20(62.50)$ \\
\hline Casual labourers & $30(22.90)$ & $101(77.10)$ \\
\hline Masons & $35(41.18)$ & $50(58.82)$ \\
\hline Others $^{\mathrm{a}}$ & $26(37.14)$ & $44(62.86)$ \\
\hline \multicolumn{3}{|c|}{ Ever had health and safety training } \\
\hline Yes & $45(29.61)$ & $107(70.39)$ \\
\hline No & $58(34.94)$ & $108(65.06)$ \\
\hline \multicolumn{3}{|l|}{ Trained from } \\
\hline Training Institute & $18(24.66)$ & $55(75.34)$ \\
\hline Workplace & $23(29.11)$ & $56(70.89)$ \\
\hline \multicolumn{3}{|c|}{ Written health and safety policy/program } \\
\hline Yes & $18(28.57)$ & $45(71.43)$ \\
\hline No & $85(33.33)$ & $170(66.67)$ \\
\hline \multicolumn{3}{|c|}{ On site hazard communication measures } \\
\hline No & $10(43.48)$ & $13(56.52)$ \\
\hline Yes & $93(31.53)$ & $202(68.47)$ \\
\hline \multicolumn{3}{|c|}{ Workplace Supervision } \\
\hline Good & $87(32.22)$ & $183(67.78)$ \\
\hline Poor & $16(33.33)$ & $32(66.67)$ \\
\hline \multicolumn{3}{|l|}{ PPE Provision } \\
\hline Employer & $60(27.52)$ & $158(72.48)$ \\
\hline Worker & $43(43.00)$ & $57(57.00)$ \\
\hline \multicolumn{3}{|c|}{ Poor safety environment } \\
\hline No & $55(26.19)$ & $155(73.81)$ \\
\hline Yes & $48(44.44)$ & $60(55.56)$ \\
\hline
\end{tabular}

Others $^{\mathrm{a}}=$ Designers, electricians, equipment operators, supervisors, cooks, guards, plumbers and trainees

reported that experience less than 1 year $[39,40]$ increases the risk of injuries. Just as noted in other literature [25] besides lack of use of PPE as well as other safety promotion measures at different sites, high prevalence among the experienced may be due to the fact that experienced workers may get used to the working environment and take safety measures for granted thus exposure to hazards and increased risk of injury.

We also found that prevalence of injury among workers whose daily income was in the third and fourth quartile ( $\geq 3.2$ USD) was 1.72 times than that among those whose daily income was the first or second quartile. This implies that the prevalence of accidents was lower among workers who earn less which is contrary to the findings by other scholars $[41,42]$ who reported high risk of occupational injuries among workers with low income levels. Though not plausible in Ugandan literature, 
Table 4 Behavioural Factors and Injury Prevalence among Construction Workers in Kampala, Uganda

\begin{tabular}{|c|c|c|}
\hline \multirow[t]{2}{*}{ Variables } & \multicolumn{2}{|l|}{ Injury } \\
\hline & Yes n (\%) & No n (\%) \\
\hline \multicolumn{3}{|c|}{ Alcohol Drinking } \\
\hline No & $76(33.63)$ & $150(66.37)$ \\
\hline Yes & $27(29.35)$ & $65(70.65)$ \\
\hline \multicolumn{3}{|c|}{ Type of alcohol taken } \\
\hline Local & $21(27.71)$ & $56(72.73)$ \\
\hline Packaged & $2(33.33)$ & $4(66.67)$ \\
\hline \multicolumn{3}{|c|}{ Drink alcohol before work } \\
\hline No & $17(28.81)$ & $42(71.19)$ \\
\hline Yes & $8(27.59)$ & $21(72.41)$ \\
\hline \multicolumn{3}{|c|}{ Drink alcohol at work } \\
\hline No & $20(34.48)$ & $38(65.52)$ \\
\hline Yes & $5(19.23)$ & $21(80.77)$ \\
\hline \multicolumn{3}{|c|}{ Khat Chewing } \\
\hline No & $95(33.33)$ & $190(66.67)$ \\
\hline Yes & $8(24.24)$ & $25(75.76)$ \\
\hline \multicolumn{3}{|c|}{ Chew khat before going to work } \\
\hline No & $6(30.0)$ & $14(70.00)$ \\
\hline Yes & $3(37.5)$ & $5(62.50)$ \\
\hline \multicolumn{3}{|c|}{ Chew khat at work } \\
\hline No & $6(37.5)$ & $10(62.50)$ \\
\hline Yes & $3(25.0)$ & $9(75.00)$ \\
\hline \multicolumn{3}{|c|}{ Cigarette Smoking } \\
\hline No & $91(32.73)$ & $187(67.27)$ \\
\hline Yes & $12(30.00)$ & $28(70.00)$ \\
\hline \multicolumn{3}{|c|}{ Kind of cigarettes smoked } \\
\hline Industrial & $8(36.36)$ & $14(63.64)$ \\
\hline Local & $3(23.08)$ & $10(76.92)$ \\
\hline \multicolumn{3}{|c|}{ Sleeping disorder } \\
\hline No & $63(65.63)$ & $152(68.47)$ \\
\hline Yes & $33(34.38)$ & $70(31.53)$ \\
\hline \multicolumn{3}{|c|}{ Job dissatisfaction } \\
\hline No & $36(46.75)$ & $174(72.20)$ \\
\hline Yes & $67(27.80)$ & $41(53.25)$ \\
\hline \multicolumn{3}{|l|}{ Job stress } \\
\hline No & $35(22.88)$ & $97(58.79)$ \\
\hline Yes & $68(41.21)$ & $118(77.12)$ \\
\hline \multicolumn{3}{|c|}{ Risk taking behaviour } \\
\hline No & $71(29.83)$ & $167(70.17)$ \\
\hline Yes & $32(40.00)$ & $48(60.00)$ \\
\hline
\end{tabular}

Table 4 Behavioural Factors and Injury Prevalence among Construction Workers in Kampala, Uganda (Continued)

\begin{tabular}{lll}
\hline Variables & Injury & \\
\cline { 2 - 3 } & Yes n (\%) & No n (\%) \\
\hline Use of PPE & $36(34.62)$ & $68(65.38)$ \\
$\quad$ Always & $52(35.37)$ & $95(64.63)$ \\
Sometimes & $15(22.39)$ & $52(77.61)$ \\
Never &
\end{tabular}

authors mention that wages always increase as workplace risks increase [43]. We may also speculate that high-risk tasks could have been offered at a high pay to attract workers' interest thus increased exposure and the observed high injury prevalence. It was also observed that the prevalence of injury was higher among workers with more than 4 years of experience. People spend more time in their workplace than even their homes, hence workplaces become part of their life yet it involves many hazards thus high risk for occupational injuries. Construction workers even most of the times live away from their homes and in substandard accommodation [27]. Although many studies have indicated that extended working hours per day or week [21, 24, 26], safety and health training of construction workers reduce occupational injuries [37, 44, 45], these factors were not statistically significantly associated with injury occurrence in this study.

Among respondents who perceived that their work environment was not safe, the prevalence on injury was 1.5 times higher as compared to those who perceived that their work environment was safe. Other scholars [21, 24, 46] have also indicated that poor perception of workplace safety is a predictor of workplace injury although a promoter of safety culture at the same time [46] arguing that workers with positive perception of their workplace safety are less likely to report accidents as well as a lower number of self-reported injuries compared to those with negative perception [24]. Although competent supervision is reported to promote safety and health in workplaces [24, 26, 47], in this study, it was not significantly associated with high prevalence of injury among workers. This may be because most of the workers reported good supervision at their workplaces hence significant differences could not be detected.

Consistent with other studies, this study indicated that the prevalence of occupational injuries was 1.63 times among workers who were dissatisfied with their job as compared to those who were satisfied. This is in line with Osman and Kumie [48] who found that workers who were dissatisfied with their assigned jobs were 1.8 times more likely to be injured compared to those who were satisfied. This may be attributed to the fact that satisfaction affects workers' commitment to workplace 
Table 5 Factors associated with occupational injuries among building construction workers in Kampala, Uganda

\begin{tabular}{|c|c|c|c|c|c|c|}
\hline \multirow[t]{2}{*}{ Variables } & \multicolumn{2}{|l|}{ Injury } & \multirow[t]{2}{*}{ CPR $[95 \% \mathrm{Cl}]$} & \multirow[t]{2}{*}{$P$-value } & \multirow[t]{2}{*}{$\mathrm{aPR}[95 \% \mathrm{Cl}]$} & \multirow[t]{2}{*}{$P$-value } \\
\hline & Yes & No & & & & \\
\hline \multicolumn{7}{|l|}{ Work designation } \\
\hline Carpenters & $12(37.50)$ & $20(62.50)$ & 1 & & 1 & \\
\hline Causal labourers & $30(22.90)$ & $101(77.10)$ & $0.61[0.37-1.05]$ & 0.07 & $0.62[0.38-1.01]$ & 0.66 \\
\hline Masons & $35(41.18)$ & $50(58.82)$ & $1.09[0.65-1.83]$ & 0.72 & $0.80[0.50-1.28]$ & 0.36 \\
\hline Others $^{\dagger}$ & $26(37.14)$ & $44(62.86)$ & $0.99[0.57-1.70]$ & 0.97 & $1.19[0.71-1.77]$ & 0.59 \\
\hline \multicolumn{7}{|l|}{ Sex } \\
\hline Female & $6(20.69)$ & $23(79.31)$ & 1 & & 1 & \\
\hline Male & $7(33.56)$ & $192(66.44)$ & $1.62[0.78-3.37]$ & 0.195 & $1.19[0.61-2.35]$ & 0.60 \\
\hline \multicolumn{7}{|c|}{ Highest Education Level } \\
\hline Tertiary & $28(34.15)$ & $54(65.85)$ & 1 & & 1 & \\
\hline Primary & $24(30.77)$ & $54(69.23)$ & $0.90[0.57-1.41]$ & 0.30 & $1.05[0.67-1.64]$ & 0.82 \\
\hline Secondary & $49(32.67)$ & $101(67.33)$ & $0.95[0.65-1.39]$ & 0.71 & $1.15[0.79-1.66]$ & 0.44 \\
\hline None & $2(25.00)$ & $6(75.00)$ & $0.73[0.21-2.53]$ & 0.21 & $1.42[0.57-3.54]$ & 0.45 \\
\hline \multicolumn{7}{|l|}{ Age } \\
\hline $35+$ & $11(22.0)$ & $39(79.0)$ & 1 & & 1 & \\
\hline$\leq 24$ & $42(36.52)$ & $73(63.48)$ & $1.66[0.93-2.95]$ & 0.17 & $2.09[1.20-3.65]$ & $0.009^{*}$ \\
\hline $25-34$ & $50(32.68)$ & $103(67.32)$ & $1.48[0.84-2.63]$ & 0.08 & $1.68[0.97-2.89]$ & 0.06 \\
\hline \multicolumn{7}{|l|}{ Employment Terms } \\
\hline Contract & $25(28.74)$ & $62(71.26)$ & 1 & & 1 & \\
\hline Temporary & $78(33.77)$ & $153(66.23)$ & $1.17[0.80-1.71]$ & 0.402 & $0.91[0.63-1.32]$ & 0.63 \\
\hline \multicolumn{7}{|c|}{ Experience in building Construction } \\
\hline $1-4$ years & $28(24.14)$ & $88(75.86)$ & 1 & & 1 & \\
\hline$<1$ year & $44(33.59)$ & $87(66.41)$ & $1.39[0.93-2.08]$ & 0.11 & $1.14[0.78-1.64]$ & 0.49 \\
\hline$>4$ years & $31(43.66)$ & $40(56.34)$ & $1.81[1.19-2.74]$ & $0.005^{*}$ & $1.37[0.91-2.07]$ & 0.13 \\
\hline \multicolumn{7}{|c|}{ Ever had health and safety training } \\
\hline Yes & $45(29.61)$ & 107 (70.39) & 1 & & 1 & \\
\hline No & $58(34.94)$ & $108(65.06)$ & $1.18[0.85-1.62]$ & 0.31 & $1.20[0.88-1.64]$ & 0.24 \\
\hline \multicolumn{7}{|l|}{ Working hours } \\
\hline $8-10$ & $44(28.39)$ & $111(71.61)$ & 1 & & 1 & \\
\hline $11-12$ & $59(36.20)$ & $104(63.80)$ & $1.27[0.92-1.76]$ & 0.14 & $1.05[0.77-1.44]$ & 0.73 \\
\hline \multicolumn{7}{|c|}{ Daily income (Quartiles) } \\
\hline First & $24(23.3)$ & $83(38.60)$ & 1 & & 1 & \\
\hline Second & $18(17.48)$ & $64(29.77)$ & $0.98[0.57-1.67]$ & 0.93 & $0.91[0.54-1.51]$ & 0.75 \\
\hline Third & $32(31.07)$ & $38(17.67)$ & $2.03[1.31-3.15]$ & $0.001^{*}$ & $1.72[1.06-2.80]$ & $0.028^{*}$ \\
\hline Fourth & $29(28.16)$ & $30(13.95)$ & $2.19[1.41-3.19]$ & $<0.001^{*}$ & $1.72[1.07-2.77]$ & $0.025^{*}$ \\
\hline \multicolumn{7}{|l|}{ Job dissatisfaction } \\
\hline No & $36(46.75)$ & $174(72.20)$ & 1 & & 1 & \\
\hline Yes & $67(27.80)$ & $41(53.25)$ & $1.68[1.23-2.30]$ & $0.001^{*}$ & $1.63[1.17-2.27]$ & $0.004^{*}$ \\
\hline \multicolumn{7}{|l|}{ Job stress } \\
\hline No & $35(22.88)$ & $97(58.79)$ & 1 & & 1 & \\
\hline Yes & $68(41.21)$ & $118(77.12)$ & $1.80[1.27-2.54]$ & $0.001^{*}$ & $1.72[1.22-2.41]$ & $0.002^{*}$ \\
\hline
\end{tabular}


Table 5 Factors associated with occupational injuries among building construction workers in Kampala, Uganda (Continued)

\begin{tabular}{|c|c|c|c|c|c|c|}
\hline \multirow[t]{2}{*}{ Variables } & \multicolumn{2}{|l|}{ Injury } & \multirow[t]{2}{*}{ CPR $[95 \% \mathrm{Cl}]$} & \multirow[t]{2}{*}{$P$-value } & \multirow[t]{2}{*}{ aPR[95\% Cl] } & \multirow[t]{2}{*}{$P$-value } \\
\hline & Yes & No & & & & \\
\hline \multicolumn{7}{|c|}{ Poor safety environment } \\
\hline No & $55(26.19)$ & $155(73.81)$ & 1 & & 1 & \\
\hline Yes & $48(44.44)$ & $60(55.56)$ & $1.69[1.24-2.31]$ & $0.001^{*}$ & $1.51[1.10-2.05]$ & $0.009^{*}$ \\
\hline \multicolumn{7}{|c|}{ Risk taking behaviour } \\
\hline No & $71(29.83)$ & $167(70.17)$ & 1 & & 1 & \\
\hline Yes & $32(40.00)$ & $48(60.00)$ & $1.34[0.96-1.86]$ & 0.08 & $1.24[0.87-1.78]$ & 0.22 \\
\hline \multicolumn{7}{|l|}{ PPE Provision } \\
\hline Employer & $60(27.52)$ & $158(72.48)$ & 1 & & 1 & \\
\hline Workers & $43(43.00)$ & $57(57.00)$ & $1.56[1.14-2.13]$ & $0.005^{*}$ & $1.47[1.05-2.05]$ & $0.02^{*}$ \\
\hline \multicolumn{7}{|l|}{ Use of PPE } \\
\hline Always & $36(34.62)$ & $68(65.38)$ & 1 & & 1 & \\
\hline Sometimes & $15(22.39)$ & $52(77.61)$ & $0.64[0.38-1.08]$ & 0.10 & $0.57[0.34-0.95]$ & $0.03^{*}$ \\
\hline Never & $52(35.37)$ & $95(64.63)$ & $1.02[0.72-1.44]$ & 0.90 & $0.78[0.55-1.10]$ & 0.16 \\
\hline
\end{tabular}

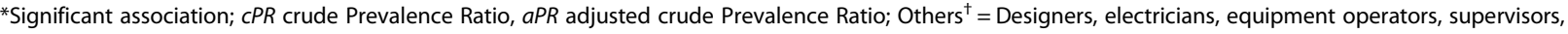
cooks, guards, plumbers and trainees

procedures and directions, which may increase their risks for occupational injury. Being about a balance between employee's objectives and those of the organization, job satisfaction becomes such a controversial issue to understand and deal with from either sides. Dissatisfied workers may find no meaning and reason to take responsibility or focus on safety precautions which may exacerbate their risk for injury [21].

Workers with job stress were about two times more likely to experience injuries compared to those who never had job stress. Job stress is a complex issue but its association with injury experience may be due to both negative perception of the work environment, working at unbearable speeds or for long periods as well as need to follow appropriate procedures thus lack of concentration on safety precaution and consequently the increased injury risk. The findings of this study support other studies that have also identified stress as an important risk factor for occupational injury [24, 36, 49-51]. Stress may be due to work burden, repetitive work, and job uncertainty [52] thus complicated tasks may lead to job stress which through many pathways may lead to injury, for, example a person stressed due to fear of falling [27] and perceived poor work environment [21] may end up getting an injury due to operation with little confidence.

Khat chewing was not associated with building construction accidents in this study yet it has been found to be a risk factor for occupational injury in other studies especially when there is addiction [20,48]. This could have been due to the small number of workers found to chew khat while at work thus losing power for comparison. The small number of workers could have been due to under reporting because of social desirability bias, as some workers may not admit chewing khat at work because of their prior knowledge that it is a negative behaviour.

The prevalence of injury was 1.47 times among those who were not provided with PPE by their employers compared to their counterparts who were provided with PPE. This could be attributed to the fact that majority of workers earned low income, which may limit their capacity to purchase, own and use PPE. However, use of PPE has been reported to reduce occurrence of occupational injuries $[25,53]$.

\section{Limitations}

This study did not go without limitations. Recall bias among respondents was a potential problem since the questions required 6 months recall of past events of injury. In this regard, respondents who sustained serious injuries could have easily remembered the injuries compared to those who experienced minor injuries. Social desirability could have occurred because of the questions that required one to answer behavioural and practices. Underrepresentation could have occurred since the study only considered registered construction sites; unregistered construction sites may have been missed. However, the findings of this study can be generalised beyond registered sites since workers do not differ much and registration does not necessary come with safety inspections.

\section{Conclusion}

There was a relatively high prevalence of injuries mostly resulting from cuts and mostly suffered on night duty. Upper and lower extremities were the most hurt parts of 
the body during injury leading to loss of a substantial number of productive days. Daily income above the second quartile, job dissatisfaction, job stress, PPE provision and use and poor safety environment were significantly associated with occupational injuries. This could affect the health and wellbeing of construction workers. Occupational injury prevention and control measures, which include approaches integrating education for behaviour change, advocacy and training workers to demand for their rights to safety and protection at work, and legislation enforcement should be implemented in Uganda. Finally, more analytical studies should be conducted to inform control and prevention efforts in Uganda.

\begin{abstract}
Abbreviations
APRs: Adjusted Prevalence Ratios; APWM: Accidents per working month; cPRs: crude Prevalence Ratios; ILO: International Labour Organisation; KCCA: Kampala Capital City Authority; LMICs: Middle and low-income countries; MoGLSD: Ministry of Gender, Labour and Social Development; OSH: Occupational Safety and Health; PPE: Personal Protective Equipment; USA: United States America; USD: United States Dollar
\end{abstract}

\section{Acknowledgments}

We wish to thank Kampala Capital City Authority for cooperation in acquiring lists of building construction sites and data collectors for their support and making this study a success.

\section{Authors' contributions}

AK, SW, and WB designed the research, AK conducted the research, analysed the data and wrote first draft of the manuscript. NR, AAH, JCS and JB reviewed the results from the analysis and the entire manuscript. JB and JCS made major contributions to the manuscript. All authors read and approved the final manuscript.

\section{Funding}

Funding for this study came from the Makerere University-Johns Hopkins University Chronic Consequences of Trauma, Injuries, and Disability across the Lifespan in Uganda Program, grant \#D43TW009284 from the Fogarty International Center, National Institute of Health of the United States of America. The funders had no role in the whole study process, decision to publish, or manuscript preparation.

\section{Availability of data and materials}

All the significant data supporting our findings is contained within the manuscript. However, all supplementary datasets analysed during the current study are available from the corresponding author on reasonable request.

\section{Ethics approval and consent to participate}

Ethical approval was obtained from The Higher Degree Research and Ethics Committee of Makerere University School of Public Health. Administrative permission was sought from Kampala Capital City Authority and all construction companies that managed the study sites. Verbal consent as approved by the ethics committee was obtained from every participant, and only non-identifiable information was collected. Verbal consent was opted for because most participants were illiterate and this study posed minimum risk to the participants.

\section{Consent for publication}

Not applicable.

\section{Competing interests}

The authors declare that they have no competing interests.

\section{Author details}

${ }^{1}$ Makerere University School of Public Health, P. O. Box 7072, Kampala, Uganda. ${ }^{2}$ Marquette University, Milwaukee, USA.
Received: 28 September 2018 Accepted: 17 October 2019

Published online: 04 November 2019

\section{References}

1. ILO. Occupational Safety and Health: Synergies Between Security and Productivity. Geneva: ILO; 2006.

2. Elgstrand K, Petersson N. OSH for Development. Stockholm: Royal Institute of Technology; 2010.

3. ILO. Safety and Health at work: A vision for sustainable prevention. In: Report to XX World Congress on Safety and Health at Work. Frankfurt: International Labor Organization; 2014.

4. ILO. Decent work - Safe work, Introductory report to the XVIIth World Congress on Safety and Health at Work. Orlando: International Labor Organization; 2005.

5. Lingard H, Rowlinson S. Occupational Health and Safety in Construction project management. New York: Spon Press; 2005.

6. Brunette MJ. Construction safety research in the United States: targeting the Hispanic workforce. Inj Prev. 2004;10:244-8.

7. Arndt $\mathrm{V}$, et al. Construction work and risk of occupatonal disability: a ten year follow-up of 14,474 male workers. Occup Environ Med. 2005;62:559-66.

8. Health and Safety Executive. Health and safety in construction in Great Britain, 2014. London: Health and Safety Executive; 2014

9. European Commission. Directorate-General for Employment and Social Affairs. Unit EMPL/D. European Statistics on Accidents at Work (ESAW): Methodology. Luxembourg: Office for Official Publications of the European Communities; 2001.

10. Gürcanli GE, Müngen U. Analysis of construction accidents in Turkey and responsible parties. Ind Health. 2013;51(6):581-95.

11. Hamalainen P, Takala J, Saarela KL. Global estimates of occupational accidents. Saf Sci. 2006:44:137-56.

12. Tanzania, N.A.O.-T.U.R.o. A performance audit report on the management of occupational health and safety in Tanzania, 2013. Dar es Salaam: National Audit Office; 2013.

13. Cokeham, M., Tutesigensi, A, An investigation of construction accidents in Rwanda: Perspectives from Kigali Proceedings of the Institution of Civil Engineers: Management, Procurement and Law 166, 2013. 166(4):179-184.

14. Lubega $\mathrm{H}$, Kiggundu BM, Tindiwensi D. An Investigation into the causes of Accidents in the construction Industry in Uganda. Kampala: Ministry of works Housing and communication; 2000.

15. MoGLSD. Occupational Safety and Health Profile for Uganda. Kampala: Ministry of gender, labour and social development; 2004

16. MoGLSD. Accidents Register. Kampala: Occupational safety and health department, Ministry of Gender, Labour and Social Development; 2009.

17. Irumba R. Spatial analysis of construction accidents in Kampala, Uganda. Safety Sci. 2014;64:109-20.

18. UBOS and UNFPA. National Population and Housing Census, Provisional Results. Kampala: Uganda Bureau of Statistics (UBOS); 2014.

19. Alinaitwe, H., J.A. Mwakali, and H. Bengt, Analysis of Accidents on Building Construction sites reported in Uganda during 2001-2005. CIB World Building Congress, 2007. 2007-174(174):1208-1232.

20. Chau N, et al. Relationship between Sme individual Cahracteristics and occupational accidents in the construction industry: a case control study on 880 victims of accidents Occcured during a two-year period. J Occup Health. 2002:44:131-9.

21. Adane MM, et al. Occupational Injuries Among Building Construction Workers in Gondar City, Ethiopia. Occup Med Health Aff. 2013:1(125):5.

22. Apurna KG, Ashis B, Nearkasen C. Relationships of Working Conditions and Individual Characteristics to Occupational Injuries: A Case-Control Study in Coal Miners. J Occup Health. 2004;46:470-80.

23. Jenkins DC, et al. A scale for the estimation of sleep problems in clinical research. J Clin Epidemiol. 1988:41(4):313-21.

24. Abbas RA, Zalat MM, Ghareeb NSE. Non-fatal occupational injuries and safety climate: a cross-sectional study of construction building Workers in Mit-Ghamr City, Dakahlia governorate, Egypt. Open J Safety Sci Technol. 2013;3(4):69-79.

25. Tadesse S, Israel D. Occupational injuries among building construction workers in Addis Ababa, Ethiopia. J Occup Med Toxicol. 2016;11:16.

26. Dembe $A E$, et al. The impact of overtime and long work hours on occupational injuries and illnesses: new evidence from the United States. Occup Environ Med. 2005;62:588-97. 
27. ILO. Safety in numbers: Pointers for a global safety culture at work. Geneva: International Labour Organization; 2003. p. 3-14.

28. Office of Communications, Occupational Safety and Health Administration, United States Department of Labour. Washington, DC: 2015. https://www. osha.gov/oshstats/commonstats.html.

29. Dong $X$, Wang $X$, Daw C. Fatal falls among older construction workers. Hum Factors. 2012;54(3):303-15.

30. Forst $\mathrm{L}$, et al. Traumatic occupational injuries in Hispanic and foreign born workers. Am J Ind Med. 2010;53(4):344-51.

31. U.S.Bureau of Labor Statistics. Survey of Occupational Injuries and IIInesses (Table R2). Washington, D.C: 2010. p. 1.

32. Jørgensen $\mathrm{K}$, Laursen B. Absence from work due to occupational and nonoccupational accidents. Scand J Public Health. 2013;41(1):18-24.

33. Weil D. Valuing the economic consequences of work injury and illness: a comparison of methods and findings. Am J Ind Med. 2001:40(4):418-37.

34. Leigh JP. Economic burden of occupational injury and illness in the United States. Milbank Q. 2011;89(4):728-72.

35. OSHA. Add value To your business to your workplace to your life in job safety and health quarterly. Washington DC: Occupational Safety and Health Administration; 2002.

36. Ekpenyong CE, Inyang UC. Associations Between Worker Characteristics, Workplace Factors, and Work-Related Musculoskeletal Disorders: A CrossSectional Study of Male Construction Workers in Nigeria. Int J Occup Saf Ergon. 2014;20(3):447-62.

37. Bena A, et al. Effectiveness of the training program for Workers at Construction Sites of the high-speed railway line between Torino and Novara:impact on injury rates. Am J Ind Med. 2009;52:965-72.

38. Bena $A$, et al. Job tenure and work injuries: a multivariate analysis of the relation with previous experience and differences by age. BMC Public Health. 2013;13:869.

39. Shah KC, Mehta H. Study of Injuries among Construction Workers in Ahmedabad City, Gujarat. Ind J Pract Doctor. 2009;5(6):1-5.

40. Gonzalez-Delgado M, et al. Factors Associated with Fatal Occupational Accidents among Mexican Workers: A National Analysis. PLoS One. 2015; 10(3):e0121490.

41. Zheng $L$, et al. Nonfatal work-related injuries among agricultural machinery operators in northern China: a cross-sectional study. Injury. 2014;45(3):599-604.

42. Berecki-Gisolf J, et al. Determinants of workplace injury among Thai Cohort Study participants. BMJ Open. 2013;3(7):e003079.

43. Shrader-Frechette K. Environmental justice: Creating equality, reclaiming democracy. Oxford: Oxford University Press; 2002.

44. van der Molen FH, et al. Interventions to prevent injuries in construction workers. Cochrane Database Syst Rev. 2012;12:CD006251.

45. Alazab RMA. Work-related diseases and occupational injuries among workers in the construction industry. Afr Newslett Occup Health Safety. 2004;14:37-42.

46. Sparer $\mathrm{HE}$, et al. Correlation between safety climate and contractor safety assessment programs in construction. Am J Ind Med. 2013;56(12):1463-72.

47. Moradinazar M, et al. Epidemiology of Work-Related Injuries Among Construction Workers of llam (Western Iran) During 2006-2009. Iran Red Crescent Med J. 2013;15(10):e8011.

48. Osman Y, Kumie A. Assessment of occupational injuries in Tendaho Agricultural Development S.C, Afar Regional State. Ethiop J Health Dev. 2010;24(3):167-74.

49. Tiwary $\mathrm{G}$, et al. Psychosocial stress of the building construction workers. Hum Biol Rev. 2013;2(3):207-22.

50. Chan IS, Leung MY. Impact of stress on injury incidents among construction workers. In: Procs 27th Annual ARCOM Conference,5-7 September 2011. Bristol: Association of Researchers in Construction Management; 2011.

51. Leung M, Chan Y, Yuen K. Impacts of stressors and stress on the injury incidents of construction Workers in Hong Kong. J Constr Eng Manag. 2010; 136(10):1093-103.

52. Malenfant R, Rue LA, Vezina M. Intermittent work and well-being. Curr Sociol. 2007:55:814-35.

53. Tanga A, Tessema F, Jilo G. Prevalence of occupational injuries and associated factors among small-scale Industries Workers in Arba Minch Town, southern Ethiopia, 2016. Int J Pub Health Safe. 2018;3(152):2.

\section{Publisher's Note}

Springer Nature remains neutral with regard to jurisdictional claims in published maps and institutional affiliations.

\section{Ready to submit your research? Choose BMC and benefit from:}

- fast, convenient online submission

- thorough peer review by experienced researchers in your field

- rapid publication on acceptance

- support for research data, including large and complex data types

- gold Open Access which fosters wider collaboration and increased citations

- maximum visibility for your research: over $100 \mathrm{M}$ website views per year

At BMC, research is always in progress.

Learn more biomedcentral.com/submissions 